\title{
Chapter 16 \\ The Relationship Between Place and \\ Life-Course Transitions in Old-Age Social \\ Exclusion: A Cross-Country Analysis
}

\author{
Anna Urbaniak, Anna Wanka, Kieran Walsh, and Frank Oswald
}

\subsection{Introduction}

The international literature recognises that places can provide a significant social, cultural and economic context for major transitions in older people's lives (Buffel et al. 2013). Beyond this, there is also recognition that such transitions are in themselves spatial as well as temporal in structure (Diewald 2016). Coupled with evidence that where someone lives can protect against or intensify exclusion in older-age (Walsh et al. 2019), the relationship older adults maintain with their residential environment is likely to play an important role in, and perhaps mediate, their experiences of major transitions and related outcomes. In the context of social exclusion of older people, and the need to advance knowledge of its multidimensional and relative nature, unpacking such a role is fundamental to understanding how disadvantage and advantage can accumulate across critical junctures of older people's lives.

\footnotetext{
A. Urbaniak $(\bowtie)$

Irish Centre for Social Gerontology, Institute for Lifecourse and Society,

National University of Ireland Galway, Galway, Ireland

University of Vienna, Vienna, Austria

e-mail: anna.urbaniak@univie.ac.at
}
A. Wanka
University of Vienna, Vienna, Austria

Research Training Group 'Doing Transitions', Goethe University Frankfurt am Main, Frankfurt am Main, Germany

K. Walsh

Irish Centre for Social Gerontology, Institute for Lifecourse and Society,

National University of Ireland Galway, Galway, Ireland

F. Oswald

Goethe University Frankfurt am Main, Frankfurt am Main, Germany 
However, there is often a failure to think about normative transitions in older-age in spatial terms (Cutchin 2003). Furthermore, while transitions can sometimes underlie models of environmental adjustment and relocation (Golant 2011), theoretical formulations of person-environment interactions rarely explicitly interrogate their meaning for later life exclusionary and inclusionary experiences in place. These deficits sit amidst broader knowledge gaps concerning how older-age transitions, as a set of processes and events, might construct multifaceted disadvantage (Grenier 2012). As a first step in responding to these circumstances, this chapter aims to explore the role of older adult place relationships in the inclusions and exclusions that may arise from two types of transitions considered as normative in older-age.

Our analysis focuses on bereavement and retirement. Bereavement is a life event that becomes a part of nearly everyone's later life experience (Stroebe et al. 2007). Retirement can be defined as an individual's exit from the workforce at the end of their careers (Wang and Shi 2014). Both transitions can be viewed as critical processes of change that may not only impact on aspects of social connectivity in older age (Cavalli et al. 2007), but may also result in objective changes in position and power within a community, and a subjective re-positioning of self. The older adult place relationship can be understood as derived from subjective and symbolic elements (e.g. roles and attachments) that cross-cut spatial/geographic, embedded service infrastructure, and social and cultural dimensions of place (Andrews et al. 2013). We draw on the definition of multidimensional exclusion, and its six domains, outlined earlier by Walsh et al. (this volume), to inform our analysis.

First, we provide an overview of existing work on the relationship between lifecourse transitions, exclusion in later life and the older adult place relationship. Second, we draw on the concept of person-environment exchange processes, in this case spatial agency and belonging, as a potential conceptual tool to deconstruct this interrelationship. Third, we present case studies from Germany, Ireland and Poland, focusing on individual experiences of retirement and bereavement. We do not aim at a cultural comparison, but the identification of similarities in the role of place across jurisdictions. Finally, we draw conclusions from overall analysis with a view to informing future conceptual understandings of place and exclusion across the life course.

\subsection{Transitions, Exclusion and Place}

Research shows that life-course transitions are crucial periods of risk in which social inequalities and exclusion can be (re-)produced, contributing to an accumulation of disadvantage across the life course (Dannefer 2003; also see Ogg and Myck, and Van Regenmortel et al. this volume). The domains of social exclusion discussed vary by transition. Even though contemporary life-course approaches emphasise the embeddedness, contextuality, and relationality of transitions across people, time, and place (Wanka 2019), it is the social and temporal and not the spatial dimensions 
of these transitions that is the focus of most research. One exception is the field of relocation and (forced) migration in later life (De Jong Gierveld et al. 2015). Consequently, we know little about how places are involved and may mediate the relationship between life-course transitions and social exclusion.

Research suggests that different dimensions of place (e.g. infrastructure, services, neighbourhood networks), and particularly the relationship older adults maintain to their residential environment, can play a crucial role in buffering and intensifying social exclusion (Walsh et al. 2019). Several conceptual frameworks recognise the agency of communities in constructing and/or protecting against exclusion (Jehoel-Gijsbers and Vrooman 2008), while others highlight how environmental change can exclude some older residents across different domains (Scharf and Bartlam 2008). In empirical work, relationships with neighbours are often discussed as resources to prevent social exclusion (Marquet and Miralles-Guasch 2015), while risks might be exaggerated through service retrenchment, lack of social services, community deprivation and transport in rural settings (Warburton et al. 2014), and redevelopment and relocation processes, the built environment, clustered deprivation as well as crime and safety in urban environments (Scharf et al. 2002; see also Drilling et al. this section for illustrative cases of the impact of redevelopment and issues around perceived safety). In their review of the interrelationships between place, exclusion and life transitions, Urbaniak and Walsh (2019) demonstrate that mediating mechanisms of place can stem from subjective and symbolic elements, social and cultural aspects, embedded service infrastructure, and environmental change. Potential circularity in the relations between the placerelationship, social exclusion and transitions are summarised in Fig. 16.1 (adapted from Walsh 2018). Here, multidimensional exclusion in general, and that arising directly from life-course transitions, may be mediated by an older adult's place relationship. Conversely, these transitions may also alter or disrupt an older person's relationship with place and, vice versa, an older person's relationship with place may alter or disrupt transitions. Ultimately, however, studies that explicitly consider life-course transitions in place as crucial turning points for the (re-)production of social exclusion remain rare.

\subsection{Older Adults' Place Relationships: The Role of Agency and Belonging}

Here, we focus on processes of agency and belonging as two key aspects of older adults' place relationships (Wahl and Oswald 2010), and how they may provide insights into the interrelationship between place, social exclusion and life transitions.

Following Bandura (2006), agency refers to the process of becoming a change agent in one's own life by means of intentional and proactive behaviours imposed on the physical-social environment. Agency is defined as the general capacity of self-regulation embedded in environmental determinants. The focus of agency lies 


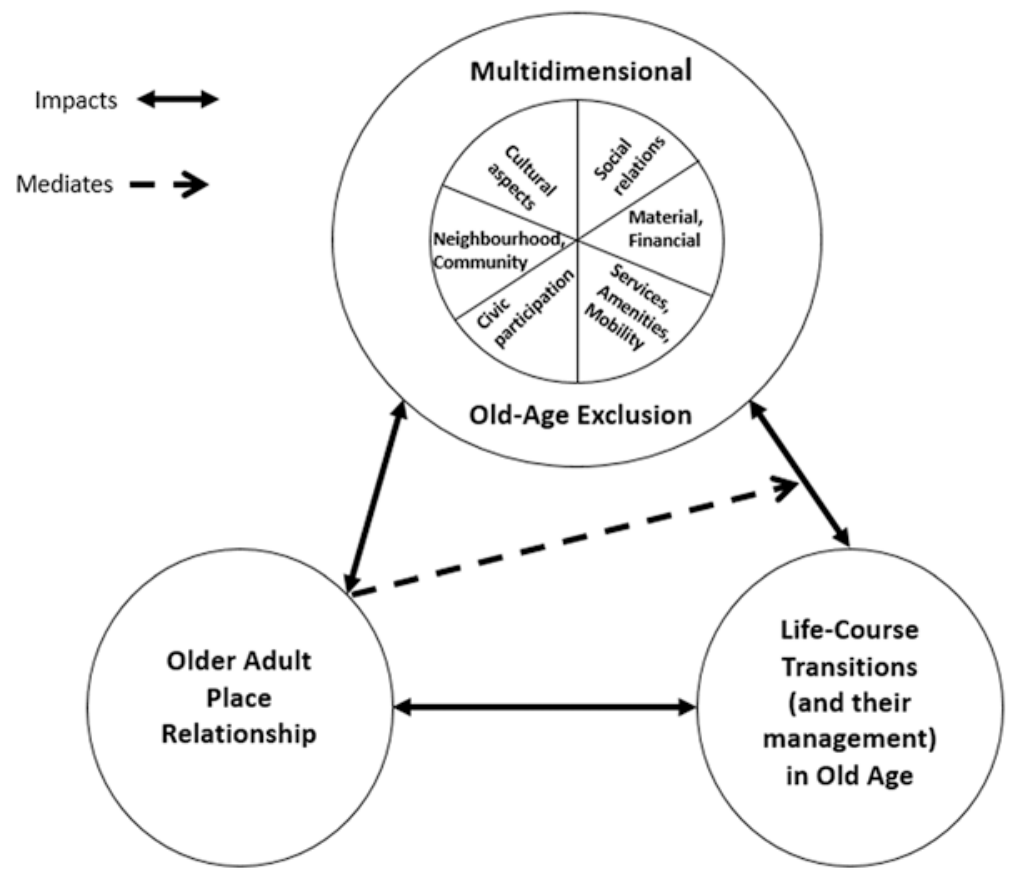

Fig. 16.1 Potential associations between older adults' place relationship, exclusion and transitions Adapted from: Walsh 2018, p. 261

in actively making use of the objective physical-social environment, including acts of using, compensating, adapting, retrofitting, creating, and sustaining places. In contrast, belonging incorporates all non-goal-oriented cognitive and emotional aspects that make a space a place, the subjective and emotional evaluations and interpretations of places, as well as processes of attachment to places over time (Oswald and Wahl 2019). That is, belonging reflects the experiential connection of attachment and bonding with the physical environment (e.g. home as a refuge, personally meaningful objects), the social environment (e.g. family members, community of people) and their intersection (Rowles 1983). Whereas spatial agency is assumed to decrease from middle to late adulthood, place attachment and belonging is considered to increase.

However, within environmental gerontology, there have been calls for a more fine-graded situational perspective of spatial agency and belonging in older adults' everyday lives (Chaudhury and Oswald 2019). Such a situational perspective can inform understandings of how spatial agency and belonging evolve dynamically across the life course, change during the course of life-course transitions, and potentially impact on multiple domains of social exclusion. Across the life course, phases of increased agentic behaviour may alternate with phases of decreased agency. The same is possible for belonging. 
With reference to Fig. 16.1, agency and belonging can be considered to play a key role within an older person's relationship with place operating across subjective and symbolic elements, and spatial/geographic, embedded service infrastructure, and social and cultural dimensions of place. Thus, a capacity for agency and belonging may mediate exclusion arising from transitions, or may in themselves be altered by those transitions. Table 16.1 summarises potential risks of such life-course transitions, and the mediating role spatial agency and belonging can play.

To explore how such risks and mediators of life-course transitions play out in individual life stories, we turn to empirical cases.

Table 16.1 The mediating role of agency and belonging processes in the face of critical life transitions and their effect on social exclusion in later life

\begin{tabular}{|c|c|c|c|}
\hline $\begin{array}{l}\text { Domains of } \\
\text { social } \\
\text { exclusion }\end{array}$ & $\begin{array}{l}\text { Potential risks/ } \\
\text { negative effects } \\
\text { of transition }\end{array}$ & $\begin{array}{l}\text { Mediating role of spatial } \\
\text { agency }\end{array}$ & Mediating role of belonging \\
\hline \multirow[t]{3}{*}{$\begin{array}{l}\text { Social } \\
\text { relations }\end{array}$} & $\begin{array}{l}\text { Withdrawal from } \\
\text { social networks }\end{array}$ & \multirow{3}{*}{$\begin{array}{l}\text { Making new or tightening } \\
\text { existing relationships with } \\
\text { neighbours (this might in turn } \\
\text { increase one's sense of } \\
\text { belonging) }\end{array}$} & \multirow{3}{*}{$\begin{array}{l}\text { Sense of belonging to the } \\
\text { local community might } \\
\text { psychologically comfort and } \\
\text { compensate for the } \\
\text { experienced losses }\end{array}$} \\
\hline & $\begin{array}{l}\mathrm{R}: \text { Loss of } \\
\text { working } \\
\text { colleagues }\end{array}$ & & \\
\hline & $\begin{array}{l}\text { B: Loss of } \\
\text { significant other }\end{array}$ & & \\
\hline \multirow[t]{3}{*}{$\begin{array}{l}\text { Material and } \\
\text { financial } \\
\text { resources }\end{array}$} & $\begin{array}{l}\text { Decrease in } \\
\text { material and } \\
\text { financial } \\
\text { resources }\end{array}$ & \multirow{3}{*}{$\begin{array}{l}\text { Relocation to a more } \\
\text { affordable area or downsizing } \\
\text { to make up for/cope with a } \\
\text { reduced financial resources } \\
\text { (this might in turn decrease } \\
\text { one's sense of belonging) }\end{array}$} & \multirow{3}{*}{$\begin{array}{l}\text { Sense of belonging to the } \\
\text { local community might } \\
\text { psychologically compensate } \\
\text { for lack of material and } \\
\text { financial resources }\end{array}$} \\
\hline & $\begin{array}{l}\text { R: Decrease in } \\
\text { employment } \\
\text { income }\end{array}$ & & \\
\hline & $\begin{array}{l}\text { B: Loss of } \\
\text { spousal income }\end{array}$ & & \\
\hline \multirow[t]{3}{*}{$\begin{array}{l}\text { Civic } \\
\text { participation }\end{array}$} & $\begin{array}{l}\text { Withdrawal from } \\
\text { civic activities }\end{array}$ & \multirow{3}{*}{$\begin{array}{l}\text { Actively engaging in local } \\
\text { volunteering (this might in } \\
\text { turn increase one's sense of } \\
\text { belonging) }\end{array}$} & \multirow{3}{*}{$\begin{array}{l}\text { Sense of belonging to a local } \\
\text { community might prevent } \\
\text { withdrawal from (local) } \\
\text { civic activities }\end{array}$} \\
\hline & $\begin{array}{l}\text { R: Loss of role as } \\
\text { an active union } \\
\text { member }\end{array}$ & & \\
\hline & $\begin{array}{l}\text { B: Loss of } \\
\text { connection to } \\
\text { clubs and parties }\end{array}$ & & \\
\hline \multirow[t]{3}{*}{$\begin{array}{l}\text { Socio-cultural } \\
\text { aspects }\end{array}$} & $\begin{array}{l}\text { Loss of social } \\
\text { roles and identity }\end{array}$ & \multirow{3}{*}{$\begin{array}{l}\text { Actively making use of local } \\
\text { opportunities to develop new } \\
\text { roles (this might in turn } \\
\text { increase one's sense of } \\
\text { belonging) }\end{array}$} & \multirow{3}{*}{$\begin{array}{l}\text { Sense of belonging might } \\
\text { strengthen/create a local } \\
\text { identity that compensates for } \\
\text { identity loss }\end{array}$} \\
\hline & $\begin{array}{l}\text { R: Loss of } \\
\text { professional role } \\
\text { and identity }\end{array}$ & & \\
\hline & $\begin{array}{l}\text { B: Loss of the } \\
\text { role of a child/ } \\
\text { spouse; loss of } \\
\text { couple identity }\end{array}$ & & \\
\hline
\end{tabular}


Table 16.1 (continued)

\begin{tabular}{l|l|l|l}
\hline $\begin{array}{l}\text { Domains of } \\
\text { social } \\
\text { exclusion }\end{array}$ & $\begin{array}{l}\text { Potential risks/ } \\
\text { negative effects } \\
\text { of transition }\end{array}$ & $\begin{array}{l}\text { Mediating role of spatial } \\
\text { agency }\end{array}$ & Mediating role of belonging \\
\hline $\begin{array}{l}\text { Services, } \\
\text { amenities and } \\
\text { mobility }\end{array}$ & $\begin{array}{l}\text { Loss of mobility, } \\
\text { decreased access } \\
\text { to services and } \\
\text { amenities }\end{array}$ & $\begin{array}{l}\text { Actively supporting existing } \\
\text { and/or creating new services } \\
\text { within one's community }\end{array}$ & $\begin{array}{l}\text { Sense of belonging might } \\
\text { psychologically compensate } \\
\text { shortcomings in local service } \\
\text { infrastructure and diminish } \\
\text { needs for mobility }\end{array}$ \\
\cline { 2 - 3 } & $\begin{array}{l}\text { R: Loss of access } \\
\text { to services } \\
\text { granted by a } \\
\text { former employer }\end{array}$ & & \\
\cline { 2 - 3 } & $\begin{array}{l}\text { B: Loss of } \\
\text { mobility after } \\
\text { the death of } \\
\text { primary driver }\end{array}$ & & \\
\hline
\end{tabular}

Note: potential risks/negative effects of transition: $\mathrm{R}$ - retirement transition; B - bereavement transition

\subsection{Illustrative Cases}

In this section, we present four empirical cases. In the first two cases of Harald and Krystyna, we focus on the mutual relationship between life-course transitions, spatial agency and sense of belonging. Since the transitions have been experienced fairly recently in each case, we cannot yet draw conclusions about the long-term effects of exclusionary impacts of transitions. With the subsequent cases of Jan and Patricia, we hence investigate further the interrelationships between transitions, older adults' place relationships and social exclusion.

The presented cases stem from three projects: "Interrelationship between lifecourse ruptures and place in old-age social exclusion - PLACED-Lives" (Ireland), "Social construction of retirement" (Poland), and "Doing Retiring" (Germany). Data collection in all projects focused on the experiences of older people in each of their areas and their experiences of different transitions in older-age. All projects follow a qualitative methodological approach and use a combination of narrative and problem-centred interviews for data collection. For the purpose of our analysis, first interviews, field notes and memos from the original studies were organised and thematically analysed (Braun and Clarke 2006) in order to capture the role of place in the bereavement and retirement transitions. Then, based on a group discussion, four illustrative cases were chosen to render visible in different ways the relationship between place, life-course transitions and social exclusion.

\section{Case 1: Bereavement, Spatial Agency and Belonging}

Harald's story illustrates how spatial agency and belonging can intensify when experiencing bereavement, and how this enhanced relationship to his residential environment helped him cope with his father's death. 
Harald is 63 years old, married and has three adult children. He lives with his wife in a suburban town in Germany, and has hardly ever engaged in the life of his community. When his father died, Harald inherited his father's house and has since spent his days sorting out, looking through memories, and making plans for the future. In this process, however, he has become more locally involved. He got in touch with many local charities and people and this engenders a renewed attachment to his hometown.

When friends and acquaintances started long-distance travel in retirement, Harald realised that his preference was to spend time in his neighbourhood. For the future he wants his daughter and two grandchildren to move into the basement of his father's former home:

'The house, and the sorting out - it reminds me that I have a past here; and when my children and grandchildren move here, too, also a future.'

\section{Case 2: Retirement, Spatial Agency and Belonging}

Krystyna's story illustrates how retiring can negatively impact one's sense of belonging, but at the same time help to increase spatial agency.

Krystyna is 61 years old, single, has no children and lives alone in a mediumsized town in the south of Poland. She worked as a CEO in a large international company, but was forced to retire at age 55 years. Krystyna's experience of retirement has been characterised by feelings of exclusion from her employment and a loss of the role she had invested so much in:

'Financially, I'm really better off... but... it's about my dignity. I gave everything to this company $[\ldots]$ and am I now supposed to be a retiree who does nothing?'

Due to Krystyna's focus on her career she neglected to spend time embedding herself in her neighbourhood. Because of this, she has not developed a strong sense of belonging and has not relied on her community to support her in making her transition into retirement. Instead, Krystyna is looking to build relations with new places and people. This is evident in her purchase of a new apartment in a metropolitan city. While she wants to enjoy living there, at the same time she is not yet ready to move in permanently. As a result, she finds herself betwixt and between her hometown and the metropolitan city: "I feel that I'm somehow torn between here and there."

\section{Case 3: The Mediating Role of Agency and Belonging in the Retirement Transition}

Jan's story illustrates how retiring can intensify social exclusion, and how spatial agency can contribute to buffering these negative outcomes - at least in some domains of social exclusion.

Jan is 54 years old, married and has no children. He lives in a village with his wife and care-dependent mother-in-law. He has worked in various jobs and has regularly changed his place of residence. Therefore, he has not developed a strong sense of belonging to any place. In his early 50s, Jan became unemployed, was diagnosed with depression, and now receives a small disability pension. Losing 
touch with his former colleagues, Jan feels lonely and anxious. He has not been able to make any contacts or engage in the neighbourhood, and misses feeling like he belongs to a community:

'I was getting more and more anxious. Nobody calls, nobody knows what I'm doing, nobody cares, no friends, no employer. The employer at least had a social responsibility. When you are retired, you get your pension benefits, but apart from that, you get nothing. Who's supposed to care?'

At some point, however, Jan got in touch with an initiative in charge of organising intergenerational co-housing facilities. Finally, he and his wife moved into one of their housing projects. In this new home he has found a new sense of community both within the co-housing initiative and across the surrounding neighbourhood. Jan has now started to engage in various civic activities:

'And that's the reason for co-housing, because all of us want to grow old together, in one house, one community. Car-sharing, growing food together, saving money, saving CO2. And we are a gain for the neighbourhood, too - that's why we receive public funding. And we'll build benches and put them in front of the supermarket for old people to rest, and our theme nights are open to the public [...].'

While the transition to retirement made Jan feel lonely and socially excluded, the neighbourhood initiative helped him to find a community and build sustainable relationships with his neighbours.

\section{Case 4: The Mediating Role of Agency and Belonging in the Bereavement Transition}

Patricia's case illustrates how bereavement, place and social exclusion are intertwined in long-term effects of exclusionary impacts of a transition.

Patricia is 80 years old, widowed and has four children. She lives alone in a city in Ireland where she worked as a civil servant before she retired. Patricia's husband died unexpectedly when she was 59 years old. Before bereavement, she was primarily involved with her family and, while she had limited social contacts within the local community, she highlights the role of her neighbours during the transition into widowhood and talks specifically about the reciprocity of relationships:

'So these neighbours now they did come in for an hour and just check on me during the day and offer to drive me shopping or whatever as well because they knew that I didn't drive, in fact it's the other way around now because he [neighbour's husband] has passed away and I drive her because she never drove.'

Patricia indicates that the death of her husband was a particular turning point for her relationship with her community, where she is now embedded in networks of reciprocity and support. Over the years, this has expanded to civic activities she is engaged in and depends also on an experiential dimension in relation to her new roles within the community:

\footnotetext{
'Yeah I mean I'm proud of the life I've made for myself in [name of the city] and the fact that I have got so involved in my retirement [active retirement group] [...] I just feel I'm making a contribution that way you know.'
} 


\subsection{Discussion}

We analysed four cases representing different stages and different settings of two types of life-course transition: bereavement and retirement. The aim was not to compare across cultures, but to highlight potential similarities in the insights that we can gather in applying a place lens to life-course transitions. The results show that bereavement and retirement impact across different domains of social exclusion and that their impacts might be mediated by spatial agency and belonging, as constituting forces within an older person's relationship with place.

Harald's and Patricia's cases illustrate the relationships between bereavement, place, and social exclusion. Harald's story demonstrates how, during the early stages of bereavement, older adults might become more agentic and develop a more intense sense of belonging to their neighbourhood. The increased involvement with his community, which might be perceived as exercising agency in place (Wahl and Oswald 2010), helped Harald to cope with his loss, knowing that, things once belonging to his parents can be used by others in the community. This newfound place-attachment might not only help in coping with transitions, but also potentially buffer exclusionary outcomes of future transitions. Patricia's story demonstrates not only the capacity of community to offer support against social exclusion that might arise from bereavement, but also the potential of individual agency in drawing on different dimensions of person-environment exchange processes (relational aspects of community, social connectivity and sense of belonging) and ultimately reinforcing the person-place relationship as a means to combat possible disadvantage in the exclusion domains of social relations, civic participation and socio-cultural aspects.

The cases of Harald and Patricia represent two different types of bereavement, yet they show similarities with regard to their interrelationships with place. Before experiencing bereavement, both were not particularly involved in their neighbourhoods. However, this changed in the course of the transition: both started to engage in local organisations, made new contacts, and acquired a renewed sense of home (Oswald and Wahl 2013). In both cases, agency (as openness and engagement in activities and social contacts in the neighbourhood) and belonging (as feeling at home and attached) to their neighbourhood increased. However, the timing when place would become relevant in the transition process differed: whereas Patricia's neighbours helped her cope with her grief from an early stage, Harald's spatial engagement occurred later in the process and was primarily mediated via the home and the objects he inherited.

We used the cases of Krystyna and Jan to illustrate relationships between retirement, place, and social exclusion. Krystyna's story highlights how during the liminal stage (Turner 1964) of the retirement transition, one's sense of belonging can diminish even if one's spatial agency increases. Krystyna's sense of belonging (Rubinstein 1989) to her hometown was mainly based upon professional connections that broke after retiring and her sense of belonging after transitioning decreased. At the same time, however, her agency increased, and she actively uses it to create new relationships to a new place. Jan's case highlights how transitions 
into retirement might result in exclusionary experiences across domains of social relations, material and financial resources and socio-cultural aspects. Through his spatial agency and sense of belonging, these effects are moderated as he tries to build up sustainable neighbourhood support networks among his co-housing neighbours, which could mediate his disadvantaged position through a newly established sense of belonging.

Both cases, albeit from the different cultural settings of Germany and Poland, represent similarities. They resonate with literature on the negative health and wellbeing impacts of involuntary exit from the labour market (Hershey and Henkens 2013). Both Krystyna and Jan lack a particular sense of belonging to their residential environment. Yet, place becomes relevant in their transitions, albeit in different ways. Whereas Krystyna acts out her liminal status by travelling and refusing to settle down, Jan longs for a sense of community and home, and relocates to an intergenerational housing facility to obtain it.

Whereas the four cases portray how place, and especially older adult's relationship to place, can mediate the relationship between life-course transitions and social exclusion, this mediating effect is not equally significant for all domains of social exclusion. In our cases, the buffering effect of the older adult's relationship to place was stronger for the domains of exclusion from social relationships, civic exclusion, and socio-cultural exclusion and less pronounced for the domains of economic exclusion and service exclusion. However, we can think of mediating effects on these domains, for example in neighbourhoods that undergo gentrification processes, where newly retired people decide to start their businesses.

Moreover, it is not only spatial agency and belonging that can mediate exclusionary processes, but vice versa. In all four cases, the possibilities to exert agency and gain a sense of belonging were facilitated by an accessible social and service infrastructure, involving clubs, voluntary organisations, or cultural initiatives. Patricia, for example, had many civic participation opportunities that she decided to pursue which allowed her to build a stronger sense of belonging that gave her a new identity, not only as a widow but as an active member of her local community. The same holds true for Jan, who could not have exerted agency in the way he did without the opportunity of an existing cohousing initiative. Krystyna and Jan relocated to access a better, more available and diverse infrastructure. Even though the cases show how spatial agency can buffer the exclusionary impacts of life-course transitions, to exert this kind of agency the respective infrastructure needs to be in place, or people need to have sufficient resources to relocate to another area - and this does not hold true for all environments and all people [see Cholat and Daconto, this volume].

\subsection{Conclusion}

The aim of this chapter was to explore the role of the older-adult place relationship in forms of inclusion and exclusion that may arise from two types of transitions in later life. Focusing on bereavement and retirement, we explored the complex and 
multidimensional exchanges between place, life-course transitions and social exclusion using four case studies from three countries. The intention was not to produce a cross-comparative cultural analysis of these relationships, but to identify potential broad commonalities in how these different factors might interrelate. Based upon these cases, we argued that there are a number of ways in which place can be involved with life-course transitions and the forms of exclusion that may sometimes arise. This includes the ways in which life-course transitions can impact on older people's relationship with place, how place can impact on the experiences of transitions themselves and how, in particular, the person-environment exchange processes of agency and belonging have the potential to hinder or magnify social exclusion that might result from life-course transitions. The presented cases are not suited to capturing the entire complexity of the interchanges between person and environments during life-course transitions, and in particular the degree of circularity in the dynamics between place, transitions and exclusion. However, the choice of cases demonstrates how spatial agency and a sense of belonging might mediate not only the way in which one experiences life-course transitions, but the way in which the transition may impact on different domains of social exclusion. Hence, certain levels of spatial agency and belonging can buffer the negative effects of life-course transitions on social exclusion, if they are enabled by respective local opportunities.

This chapter demonstrates why it is necessary to consider more actively the role of place, and the role older adults play in exerting agency in place, in processes of transition. It is exactly the interplay between locally existing opportunity structures and the way older adults make use of them and relate to them that can help buffer negative effects of life-course transitions on social exclusion in later life. Hence, simply stressing the role of individual agency is not sufficient - policy and practice instead need to enable older adults to exert spatial agency and develop a sense of belonging within a community, for example through supporting local initiatives for older adults.

This chapter has been exploratory in nature, and only in parts has hinted at macro and structural factors underlying the presented cases. Hence, we need to develop a more advanced and systematic understanding of the relationship between place, life-course transitions and social exclusion for further development of ageing policies that aim at combating social exclusion. Future research should systematically consider the ways in which national, cultural and structural contexts, different sorts of transitions, the diversity of people, neighbourhoods and communities might intersect with the role of place in exclusion arising from life-course transitions over time. This is necessary before we can conceptually map the dynamics of these complex forces with any certainty and explore their influence over the lived experience of older people in place. Nevertheless, our analysis has begun to unpack some of these dynamics and illustrates how we might begin the process of harnessing place to support older people at particular risk junctures in their lives. 


\section{Editors' Postscript}

Please note, like other contributions to this book, this chapter was written before the COVID-19 pandemic of 2020. The book's introductory chapter (Chap. 1) and conclusion (Chap. 34) consider some of the key ways in which the pandemic relates to issues concerning social exclusion and ageing.

\section{References}

Andrews, G. J., Evans, J., \& Wiles, J. L. (2013). Re-spacing and re-placing gerontology: Relationality and affect. Ageing and Society, 33(8), 1339-1373.

Bandura, A. (2006). Toward a psychology of human agency. Perspectives on Psychological Science, 1, 164-180.

Braun, V., \& Clarke, V. (2006). Using thematic analysis in psychology. Qualitative Research in Psychology, 3(2), 77-101.

Buffel, T., Phillipson, C., \& Scharf, T. (2013). Experiences of neighbourhood exclusion and inclusion among older people living in deprived inner-city areas in Belgium and England. Ageing and Society, 33(1), 89-109. https://doi.org/10.1017/S0144686X12000542.

Cavalli, S., Bickel, J. F., \& Lalive d'Epinay, C. J. (2007). Exclusion in very old age: The impact of three critical life events. International Journal of Ageing and Later Life, 2, 9-31.

Chaudhury, H., \& Oswald, F. (2019). Advancing understanding of person-environment interaction in later life: One step further. Journal of Aging Studies, 51, 100821. https://doi.org/10.1016/j. jaging.2019.100821.

Cutchin, M. P. (2003). The process of mediated aging-in-place: A theoretically and empirically based model. Social Science \& Medicine, 57(6), 1077-1090.

Dannefer, D. (2003). Cumulative advantage/disadvantage and the life course: Cross-fertilizing age and social science theory. The Journals of Gerontology Series B: Psychological Sciences and Social Sciences, 58, 327-337.

De Jong Gierveld, J., Van der Pas, S., \& Keating, N. (2015). Loneliness of older immigrant groups in Canada: Effects of ethnic-cultural background. Journal of Cross-Cultural Gerontology, 30, 251-268.

Diewald, M. (2016). Life course risks and welfare states' risk management. In M. J. Shanahan, J. T. Mortimer, \& M. K. Johnson (Eds.), Handbook of life course (pp. 677-687). Cham: Springer.

Golant, S. M. (2011). The quest for residential normalcy by older adults: Relocation but one pathway. Journal of Aging Studies, 25, 193-205. https://doi.org/10.1016/j.jaging.2011.03.003.

Grenier, A. (2012). Transitions and the lifecourse: Challenging the constructions of growing old. Bristol: Policy Press.

Hershey, D. A., \& Henkens, K. (2013). Impact of different types of retirement transitions on perceived satisfaction with life. The Gerontologist, 54(2), 232-244.

Jehoel-Gijsbers, G., \& Vrooman, C. (2008). Social exclusion of the elderly: A comparative study of EU member states. http://aei.pitt.edu/9443/2/9443.pdf. Accessed 7 Jan 2020.

Marquet, O., \& Miralles-Guasch, C. (2015). The Walkable city and the importance of the proximity environments for Barcelona's everyday mobility. Cities, 42, 258-266.

Oswald, F., \& Wahl, H.W. (2013). Creating and sustaining homelike places in own home environments. In G. D. Rowles \& M. Bernard (Eds.), Environmental gerontology (pp. 53-77). New York: Springer.

Oswald, F., \& Wahl, H.W. (2019). Physical contexts and behavioral aging. In Oxford research encyclopedia of psychology. Oxford: Oxford University Press. https://doi.org/10.1093/ acrefore/9780190236557.013.399. 
Rowles, G. D. (1983). Geographical dimensions of social support in rural Appalachia. In G. D. Rowles \& R. J. Ohta (Eds.), Aging and milieu: Environmental perspectives on growing old (pp. 111-130). New York: Academic.

Rubinstein, R. L. (1989). The home environments of older people: A description of the psychosocial processes linking person to place. Journal of Gerontology: Social Sciences, 44(2), 45-53. https://doi.org/10.1093/geronj/44.2.S45.

Scharf, T., \& Bartlam, B. (2008). Ageing and social exclusion in rural communities. In N. Keating (Ed.), Rural ageing: A good place to grow old? (pp. 97-108). Bristol: Policy Press.

Scharf, T., Phillipson, C., Smith, A., \& Kingston, P. (2002). Growing older in socially deprived areas: Social exclusion in later life. London: Help the Aged. https://www.ageuk.org.uk/ documents/en-gb/for-professionals/communities-and-inclusion/id2255_a_growing_older_in socially_deprived_areas_social_exclusion_in_later_life_2002_pro.pdf?dtrk=true. Accessed 7 Jan 2020 .

Stroebe, M., Schut, H., \& Stroebe, W. (2007). Health outcomes of bereavement. The Lancet, 370(9603), 1960-1973.

Turner, V. (1964). Betwixt and between: The liminal period in rites of passage. In J. Helm (Ed.), Symposium on new approaches to the study of religion. Proceedings of the 1964 annual spring meeting of the American Ethnological Association (pp. 4-20). Seattle: University of Washington Press.

Urbaniak, A., \& Walsh, K. (2019). The interrelationship between place and critical life transitions in later life social exclusion: A scoping review. Health \& Place, 60, 102234. https://doi. org/10.1016/j.healthplace.2019.102234.

Wahl, H.W., \& Oswald, F. (2010). Environmental perspectives on aging. In D. Dannefer \& C. Phillipson (Eds.), International handbook of social gerontology (pp. 111-124). London: Sage.

Walsh, K. (2018). Constructions of old-age social exclusion: In place and shaped by place. In M. Skinner, G. Andrews, \& M. Cutchin (Eds.), Geographical gerontology: Concepts and approaches (pp. 252-266). London: Routledge.

Walsh, K., O'Shea, E., \& Scharf, T. (2019). Rural old-age social exclusion: A conceptual framework on mediators of exclusion across the lifecourse. Ageing and Society, 1-27. https://doi. org/10.1017/S0144686X19000606.

Wang, M., \& Shi, J. (2014). Psychological research on retirement. Annual Review of Psychology, 65, 209-233. https://doi.org/10.1146/annurev-psych-010213-115131.

Wanka, A. (2019). Change ahead-Emerging life-course transitions as practical accomplishments of growing old(er). Frontiers in Sociology. Online first: https://doi.org/10.3389/ fsoc.2018.00045.

Warburton, J., Cowan, S., Winterton, R., et al. (2014). Building social inclusion for rural older people using information and communication technologies: Perspectives of rural practitioners. Australian Social Work, 67, 479-494.

Open Access This chapter is licensed under the terms of the Creative Commons Attribution 4.0 International License (http://creativecommons.org/licenses/by/4.0/), which permits use, sharing, adaptation, distribution and reproduction in any medium or format, as long as you give appropriate credit to the original author(s) and the source, provide a link to the Creative Commons license and indicate if changes were made.

The images or other third party material in this chapter are included in the chapter's Creative Commons license, unless indicated otherwise in a credit line to the material. If material is not included in the chapter's Creative Commons license and your intended use is not permitted by statutory regulation or exceeds the permitted use, you will need to obtain permission directly from the copyright holder.

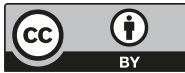

